WwW.ijbpas.com

\title{
EFFICACY OF VISHNU TAILA NASYA AND EKANGAVEERARAS IN ARDITAVATA W.S.R TO BELL'S PALSY -A CASE STUDY
}

\author{
DODDAGOUDAR SN ${ }^{1 *}$ AND ROY KB ${ }^{2}$ \\ 1: PhD Scholar, 2: Faculty \\ Department of Panchakarma, Parul Institute of Ayurveda, Parul University, Vadodara- \\ Gujarat-India
}

*Corresponding Author: Sangameshwar. N. Doddagoudar

Received 12 ${ }^{\text {th }}$ Dec. 2021; Revised 14 ${ }^{\text {th }}$ Jan. 2022; Accepted $7^{\text {th }}$ Feb. 2022; Available online $5^{\text {th }}$ March 2022

https://doi.org/10.31032/IJBPAS/2022/11.3.1054

\section{ABSTRACT}

Arditavata is one among Vatananatmaja vyadhi, Characterized by Mukhavakrata, Ekakshi Nimeelana, Ashrusrava, Lalaatavakrata, Ruja in Jatrurdvapradesha, Vaksanga, Hasitavakrata are the most common symptoms leading to disfigurement of face at one lateral side. Arditavata is well correlated with Bell's palsy which has incidence rate 6 of 23 cases per 100,000 Population /Year or about 1 in 60 to 70 people in a lifetime. It affects in all the age groups and in both sexes. It is mainly precipitated by fast life style, irregular food habits, lack of sleep and some of viral infections which are the common events of modern life. It is more prevalent in known cases of Hypertension and Diabetes. The facial nerves control a number of functions, such as blinking and closing the eyes, smiling, frowning, lacrimation, salivation, flaring nostrils and raising eyebrows, sensation of taste in the anterior two third of the tongue, which affected in Bell's Palsy. In contemporary system of medicine there is no proved medical management for Bell's palsy. And available medicines are also having its own limitations with side effects. In Ayurvedic classics there is specific line of management for Arditavata such as NasyaKarma, MoordniTaila, Tarpan and Shamanoushadhis like Ekangaveera Ras and etc.

Ekangaveerras is a herbo mineral shamanoushadhi administered as nano medicine, which is mentioned in Vatavyadhiprakarana of Brahat Nighantu Ratnakar with an indication in Arditavata and in all Vatavyadhis. Vishnutaila nasya is a choice of treatment chosen which 
expels vitiated Doshas from Shiras. Vishnutaila is of vata shamaka properties of drugs involed in it. Hence Ekangaveeraras as shamanoushadhi, Nasya Karma with Vishnutaila taken for the study and tried in treating Arditavata case w.s.r to Bell's Palsy.

Keywords: Arditavata, Ekangaveerras, Vatavyadhi, Bell's palsy, Nasyakarma INTRODUCTION

Arditavata is Ekayama by Ashtanga Hrudaya.NanatmajaVatavikara Vatakara Ahara-Vihara like biting hard things, Atihasana, UchchaBhshana, Vegadharana, etc. are the leading Nidanas Vepathu, and charmasuptata are some of Purvarupa. Arditavata is nothing but Mukharda Vakrata. Disability and Disfigurement of one lateral side of face. Clinical features of Arditavata are well correlated with Bell's palsy. Face looks Asymmetrical even at rest. Efforts to close the eye merely cause the eye balls to roll up; it is known as Bell's phenomenon. Arditavata is classified under three headings depending on Doshic predominance Vataja, Pittaja and Kaphaja. Arditavata, A Bell's palsy has become common now days. In contemporary system there is no specific line of treatment for it, only managed by steroids and neurotonics, though facial deformity and difficulty in speech are involved in a disease hence patients approaching Ayurvedic physician with lot of hope. So the clinical study is done here Nasya with Vishnutaila and Ekangaveeraras as shamanoushadhi for the rest of the symptoms present after the Nasyakarma in treating the case Arditavata w.s.r to Bell's palsy.

\section{CASE REPORT}

On June $6^{\text {th }} 2021$ A male patient of 45 yrs. came to Panchakarma OPD S.S.Ayurvedic Medical College Hospital with complaints of Pain in left Ear with Deviation of face at left side, difficulty in speaking watery discharge from left eye On examination patient with a complaints and clinical symptoms Mukhavakrata, Ekakshi Nimeelana, Ashrusrava, Lalaatavakrata, Ruja in Jatrurdvapradesha, Vaksanga, and Hasitavakrata are the most common symptoms seen in the case. And patient was diagnosed as a Arditavata (Bell's palsy). After initial assessments and with the consent of patient, admitted in hospital. Basic investigations and examinations are got it done. From second day patient planned for the Nasya treatment.

\section{Diagnostics (Lab Investigations):}




\begin{tabular}{|c|c|c|c|}
\hline $\begin{array}{c}\text { TYPE OR NAME OF } \\
\text { INVESTIGATION }\end{array}$ & $\begin{array}{c}\text { DATE OF } \\
\text { INVESTIGATIONS } \\
\text { DONE }\end{array}$ & RESULTS & UNITS/PER \\
\hline Haemoglobin & $06-06-2021$ & 13 & g/dl \\
\hline WBC count & $06-06-2021$ & $\mathbf{7 8 0 0}$ & Cells/cumm \\
\hline Platelet count & $\mathbf{0 6 - 0 6 - 2 0 2 1}$ & $\mathbf{2 . 7 8}$ & Mg/dl \\
\hline RBS & $\mathbf{0 6 - 0 6 - 2 0 2 1}$ & Non-reactive & - \\
\hline HIV/HBSAG & $\mathbf{0 6 - 0 6 - 2 0 2 1}$ & WNL & - \\
\hline $\begin{array}{c}\text { Rapid test covid (card } \\
\text { method) }\end{array}$ & $\mathbf{0 6 - 0 6 - 2 0 2 1}$ & Negative & - \\
\hline
\end{tabular}

Ashtavidha Pariksha: Nadi (Pulse): 80/min, Mala pravrutti (Stool): Asamyak Pravartana, Mutra pravrutti (Urine): Prakrutta, Jeeva (Tounge): Aliptata, Kshudha (Agni): Mandya, Shabda (Speech): Prakrutta, Sparsha (Skin): Shitoshna, Khara, Dhruka (Eyes): Prakrutta, Nidra (Sleep): Khandita, Akrutti (Stature): Madhyama, Bala (Strength): Uttama.

\section{Systemic Neurological examination}

Motor system examination was done based on Bell's phenomenon - positive on Left side of face. Patient was unable to whistle, deviation during mouth clenching with loss of furrow over the forehead and unable to do full mouth inflation. Also difficulty was there in closing the left eye fully.

\section{Treatment schedule planned:}

1st schedule of Treatment (Started on next day of admition)

$>$ Mukhabhyanga and Nasyakarma with Vishnutaila for 7 days

Dhoomapana with Haridra dhooma.

$>$ Ekangaveeraras 125mg 1tab 3 times after food for 21 days. 2nd schedule (After completion of Nasya Karma)

Ekangaveera rasa $125 \mathrm{mg} 1 \mathrm{tab}$. tid after food for 21 days.

Exercise: Balloon blowing exercise three times a day.

Face exercise in front of mirror three times a day for 5 minutes.

Total course of treatment is 21 days with follow up 14th, 21st days.

\section{PROCEDURE:}

The patient was thoroughly examined in keeping view Prakruti and Vikruti.

1st step (Mukhabhyanga with Vishnu taila): Took lukewarm oil in the container and asked the patient to sit on chair with head tilted backward direction by giving support with pillow to neck. Then did Abhyanga (massage) to whole face within specific directions that is from neck upward, from affected side to normal side of face, and zig zag direction on forehead and chin.Bhashapa swedana is done with cloth dipped in warm hot water with all precautions.

2nd step (Nasya with Vishnu taila): 
Down the patient on dhroni (massage bed) and tilt head to upward direction and ask the patient to relax. Then put Nasya $8-8$ drops in each nostril alternately and comfort the patient by rubbing nose and asked then patient to spit after 5 minutes.

3rd step (Dhoomapana):

Patient was asked to sit up and Haridra dhooma was given and asked the patient to inhale dhooma from each nostril alternately blow out from mouth till 5 minutes.
DRUGS:

VISHNU TAILA (Swalpa):

> Kalka dravya: Shalaparni,

Prushniparni, Bala Shatavari,

Erandamoola, Bruhatimoola

Vachamoola, Nagabalamoola,

Sahacharamoola.

Snehadravya: TilaTaila

Drava dravya: GoDugdha

Procedure: VishnuTaila is prepared as per Classics.

EKANGAVEERARAS:

\begin{tabular}{|c|c|c|c|}
\hline S. No. & MAIN CONTENTS & PROPORTION & BHAVANADRAYVA \\
\hline 1. & Shudhagandhaka & \multirow{11}{*}{$\begin{array}{l}\text { ALL DRAVYAS } \\
\text { SAMABHAGA. }\end{array}$} & \multirow{11}{*}{$\begin{array}{c}\text { Triphala } \\
\text { Trikatu } \\
\text { Nirgundi } \\
\text { Chitrak } \\
\text { Shigru } \\
\text { Kushtha } \\
\text { Amalki } \\
\text { Kupilu } \\
\text { Arka } \\
\text { Guduchi } \\
\text { Aadraka }\end{array}$} \\
\hline 2. & Shudhaparada & & \\
\hline 3. & Shudhakantalohabhasm & & \\
\hline 4. & Vangabhasma & & \\
\hline 5. & Naga Bhasma & & \\
\hline 6. & Tamrabhasma & & \\
\hline 7. & Abhrakabhasma & & \\
\hline 8. & Tikshnalohabhasma & & \\
\hline 9. & Nagaram & & \\
\hline 10. & Maricha & & \\
\hline 11. & Pippali & & \\
\hline
\end{tabular}

According to classics Ekangaveeraras is prepared keeping in view of dosage and other Aspects classically.

\section{ASSESSMENT OF RESULTS:}

Depending on Subjective and Objective criteria Assessment is be done basis of the response of treatment. Clinical study results are assessed on basis of grading are mentioned as Severe-3, Moderate-2, Mild$\mathbf{1}$, and Normal-0 are given.

\begin{tabular}{|c|c|c|c|c|c|c|}
\hline $\begin{array}{c}\text { S. } \\
\text { No. }\end{array}$ & SUBJECTIVE & OBJECTIVE & B.T & AT & F-1 & F-2 \\
\hline 1 & Mukhavakrata & Deviation of face & 3 & 2 & 2 & 1 \\
\hline 2 & Vaksanga & Difficulty in speech & 3 & 2 & 1 & $\mathbf{0}$ \\
\hline 3 & Stabdanetrata & Unable to close the eye & 2 & 2 & 1 & $\mathbf{0}$ \\
\hline 4 & Shirashoola & Headache & 2 & 1 & $\mathbf{0}$ & $\mathbf{0}$ \\
\hline 5 & Shrutihani & Vaksanga & 2 & 1 & $\mathbf{0}$ & $\mathbf{0}$ \\
\hline 6 & Lalatavakrata & Loss of furrow over the forehead & 3 & 2 & 1 & $\mathbf{0}$ \\
\hline
\end{tabular}


ASSESSMENT OF RESULTS: On the basis of “House Brackmann's Gradation System" assessment was done. Results of
Clinical study are on basis of grading mentioned as Severe-3, Moderate-2, Mild1 , and for Normal-0.

Table 1: Grading for assessment of clinical feature.

\begin{tabular}{|c|c|c|c|}
\hline CLINICAL FEATURE & GRADING & BEFORE TREATEMENT & AFTER TREATEMENT \\
\hline \multicolumn{4}{|c|}{ FACE: RELIEF TWITCHING OF RIGHT SIDE FACE(DEVIATION) } \\
\hline NOT PERSISTENT & $\mathbf{0}$ & & $\mathbf{0}$ \\
\hline $\begin{array}{c}\text { PERSISTENT BUT DO } \\
\text { NOT DISTURB } \\
\text { ROUTINE WORK B }\end{array}$ & 1 & 2 & \\
\hline $\begin{array}{l}\text { PERSISTENT DISTURB } \\
\text { ROUTINE WORK B }\end{array}$ & 2 & 1 & \\
\hline CONSTANT & 3 & & \\
\hline
\end{tabular}

\begin{tabular}{|c|c|c|c|}
\hline CLINICAL FEATURE & GRADING & BEFORE TREATEMENT & AFTER TREATEMENT \\
\hline \multicolumn{4}{|c|}{ EYEBROWS: DIFFICULTY IN MOVING UP LEFT EYEBROW } \\
\hline NOT PERSISTENT & 0 & & $\mathbf{0}$ \\
\hline $\begin{array}{c}\text { PERSISTENT BUT DO } \\
\text { NOT DISTURB } \\
\text { ROUTINE WORK }\end{array}$ & 1 & 1 & \\
\hline $\begin{array}{l}\text { PERSISTENT DISTURB } \\
\text { ROUTINE WORK }\end{array}$ & 2 & & \\
\hline $\begin{array}{l}\text { CONSTANT } \\
\end{array}$ & 3 & & \\
\hline
\end{tabular}

\begin{tabular}{|c|c|c|c|}
\hline CLINICAL FEATURE & GRADING & BEFORE TREATEMENT & AFTER TREATEMENT \\
\hline \multicolumn{3}{|c|}{ MOUTH: DRIFTING OF MOUTH IN LEFT SIDE ANGLE } \\
\hline $\begin{array}{c}\text { NOT PERSISTENT } \\
\begin{array}{c}\text { NOT DISTURB } \\
\text { ROUTINE WORK }\end{array}\end{array}$ & $\mathbf{0}$ & & \\
\hline $\begin{array}{c}\text { PERSISTENT DISTURB } \\
\text { ROUTINE WORK }\end{array}$ & $\mathbf{2}$ & & \\
\hline CONSTANT & $\mathbf{2}$ & & \\
\hline
\end{tabular}

\begin{tabular}{|c|c|c|c|}
\hline CLINICAL FEATURE & GRADING & BEFORE TREATEMENT & AFTER TREATEMENT \\
\hline \multicolumn{4}{|c|}{ EYE: DIFFICULTY OF CLOSING LEFT EYE } \\
\hline $\begin{array}{c}\text { PERSISTENT BUT DO } \\
\text { NOT DISTURB } \\
\text { ROUTINE WORK B }\end{array}$ & $\mathbf{0}$ & $\mathbf{2}$ & \\
\hline $\begin{array}{c}\text { PERSISTENT DISTURB } \\
\text { ROUTINE WORK }\end{array}$ & 1 & 1 & \\
\hline CONSTANT & 2 & & \\
\hline
\end{tabular}

\begin{tabular}{|c|c|c|c|}
\hline CLINICAL FEATURE & GRADING & BEFORE TREATEMENT & AFTER TREATEMENT \\
\hline \multicolumn{3}{|c|}{ TONGUE: DEVIATED TO RIGHT SIDE } \\
\hline $\begin{array}{c}\text { PERSISTENT BUT DO } \\
\text { NOT DISTURB } \\
\text { ROUTINE WORK }\end{array}$ & $\mathbf{0}$ & $\mathbf{1}$ & \\
\hline $\begin{array}{c}\text { PERSISTENT DISTURB } \\
\text { ROUTINE WORK }\end{array}$ & 1 & & \\
\hline CONSTANT & 2 & & \\
\hline
\end{tabular}




\section{DISCUSSION}

Arditavata is well correlated with Bell's palsy which has incidence rate 6 of 23 cases per 100,000 Population /Year or about 1 in 60 to 70 people in a lifetime. Arditavata laxanas are as mentioned in classics are similar to the Bell's Phenomenon in contemporary Medicine. It is facial nerve palsy. There are many treatment modalities available to manage this disorder. Ayurvedic treatment protocol is one of the best holistic ways to manage this. It is time to except the fact that Ayurveda itself having best curative approaches for such types of disease and thus it should be used worldwide to cure and to serve good treatment protocol to benefit patients. Here is a case study done as above explained Nasyakarma with Vishnutaila and Ekangaveeraras $125 \mathrm{mg}$ thrice a day as Shamanouashadhi is resulted well in short period in Arditavata chikitsa.

\section{CONCLUSION}

The nidanas explained in classics are noticed in this patient like Patient mainly has history of Chinta, Bhaya and Ratrijagarana.etc and the lakshanas explained in classics are also noticed in this case. Arditavata is most common unilateral lower motor neuron facial palsy that usually develops suddenly or spontaneously. Arditavata was successfully managed with Ayurvedic treatment such as
Snehana (oleation), Svedana (fomentation) followed by Nasyakarma. (Nasal Medication) and shamanoushadhi as Ekangaveeraars $125 \mathrm{mg}$ three times a day. The Chikitsa sidhanta followed here is Dhatuvardaka and Vatashamaka Chikitsa. as the disease belongs under Vatavyadhi. After Nasyakarma, patient found better relief in symptoms of Arditavata. There is direct indication of Nasyakarma in Arditavata by acharyas. The treatment advocated in Ayurveda for Arditavata (facial palsy) was instituted to this patient, who was cured without any further complications and side effects in holistic medicine of Ayurveda.

\section{LIST OF REFERENCES}

[1] Yadavji Trikamji Acharya, Chakrapani Dutta, Ayurveda Deepika Charaka Samhita Sutrasthana Edition 1st, Varanasi, Chaukamba Prakashana, 2000, 17/12, Page no.99.

[2] Acharya Vidhyadhara Shukla, Ravidutta Tripathi- Charaka Samhita Volume-II, edited with Vaidya manorama hindi commentary, Vatavyadhichikitsa, Chikitsastana 28/3842, Edition, Reprint, Published by Chaukhamba Sanskrit Pratishtana, Varanasi, 2010 Page- No.614 
[3] K.R. Shashtri Narve-Ashtanga Hridaya Nidanasthana15/34, edited by Hari Sadashi Shastri Paradakara published Chaukamba Surabharati prakashan Varanasi, 2002, Page.533

[4] Shastri Kaviraj Ambikadatt, Sushruta Samhita, Part-I11thedition, Varanasi, Chaukamba Prakashana, 2009, Nidana Stana 1/70-72, Page No.303.

[5] Sadashiv Shastri Paradakara Arundatta, Sarvanga Sundari, Ashtanga Hradaya, Nidanasthana 15/36, edition-1st published byChaukamba Surabharati prakashana, Varanasi, 2002, Page.No. 533.

[6] Davidson's Principle \& Practice of Medicine by Nicholas A. Boon, Nicki R. Colledge, Brian R. walker and John A. A. hunter, Churchill Livingstone Elsevier publication 20th edition 2006

[7] Acharya Vidhyadhara Shukla, Ravidutta Tripathi- Charaka Samhita Volume-II, edited with Vaidyamanorama hindi commentary, Vatavyadhichikitsa, Chikitsastana 28/99, Edition, Reprint, Published by-Chaukhamba Sanskrit Pratishtana, Varanasi, 2010, Page- No.705
[8] Brahan Nighantu Ratnakar,

Panchama Bhaga, Chaptr-

Vatavyadhi karma vipakah, by Krishnashastri Ganga Vishnu Laxmivenkateshwar mudranalaya Publication Kalyan- Mumbai page 509-510-pg.436

[9] Shri Kaviraj Ambikadatta Shastri Ayurvedacharya, Bhaishajya Ratnavali with Shri Kaviraj Ambikatanaya data Shastri Ayurvedacharya, Bhaishajya Ratnavali with 2005. Vata Vyadhi

Chikitsa Adhikara 26/2224,Page.No.-530

[10] K.R.Shashtri Narve-Ashtanga Hridaya Nidanasthana 15/34, edited by Hari Sadashiv Shastri Paradakara published Chaukamba Surabharati prakashan, Varanasi, 2002, Page.533.

[11] Acharya Sushruta, Sushruta Samhita, Nidana Sthana, Cpt-1, Shloka No-70-71, Edited by Ambika Datta Shastri, published by Choukhamba Sanskrit Samsthana reprint -2016, Page no303

[12] Vaidya Lakshmipati Shstri, Edited By Bhaisagratna Brahmasagar Shastri, Yogaratnakar with Vidyotini Hindi commentary, Varanasi: Choukamba Sanskrit 
Samsthana, $8^{\text {th }}$ edition, 2003. Vata

Vyadhi Nidana Page. No-509 and

510

[13] Bhavamishra, Bhavaprakasha part

-2.Chikitsa Prakarana, chapter-24, Shloka no 64, 66, edited by Brahma Sankara Mishra, published by Choukhamba Sanskrit Sansthan, Varanasi, 2003.

Page no -234.

[14] Srivastava Dr. Smt. Shailaja Sharangadhara Samhita of Acharya Sharangadhara jivanprda Hindi Commentary Reprint Ed.2011, Varanasi, Chaukamba Orientaliya, Chp.13/32, Page.No.486.

[15] House, J, W., Brakmann, D, E, Facialnerve grading system. Otolaryngol, Head Neck Surg, [93]146147, 1985, https;//sorensenclinic.com/microsu rgery/house-brakmann/s. 